\title{
NOVENAS, SAMBAS E TORÉS: REDE RITUAL, TRADIÇÃO DE CONHECIMENTO E IDENTIDADE INDÍGENA KAPINAWÁ
}

\author{
LARA ERENDIRA ALMEIDA DE ANDRADE ${ }^{1}$
}

\begin{abstract}
RESUMO
0 trabalho apresentado neste artigo é fruto de pesquisa desenvolvida durante 0 mestrado em antropologia na Universidade Federal da Paraíba (2012-2014). Aqui apresento parte da discussão da dissertação que reflete como os rituais possibilitaram a construção de redes e a consequente constituição do sentido de pertencimento étnico entre os Kapinawá. As memórias e sentidos dados às festas das novenas e os benditos aí cantados, aos sambas de coco e sambas, que dão 0 ritmo da batida dos pés, e ao toré e toantes, entoados junto ao chacoalhar do maracá, são peças chaves na compreensão dessa identidade. Analiso como se constrói uma tradição de conhecimento que possibilitou a integração dos diversos agrupamentos familiares do entorno da Serra do Macaco, que se organizaram pela reivindicação da identidade indígena. No texto, analiso também, mais detidamente, a parte do território que ainda não está regularizada, chamada localmente de "Área Nova".
\end{abstract}

\section{PALAVRAS-CHAVE \\ Identidade Kapinawá; Rede ritual; Tradição de conhecimento.}

\section{NOVENAS, SAMBAS E TORÉS: RITUAL NETWORK, TRADITION OF KNOWLEDGE AND KAPINAWÁ INDIGENOUS IDENTITY}

\begin{abstract}
The work presented in this article is the result of a research developed during the master's degree in anthropology at the Universidade Federal da Paraíba (2012-2014). Here I present part of the discussion of the dissertation that reflects about how rituals enabled the construction of networks and the consequent constitution of the sense of ethnic belonging among the Kapinawá. The memories and meanings given to the festas das novenas (novena festivities) and the benditos (blessings) sung there, to the sambas de coco and sambas, which give the rhythm to the feet tapping, and to the toré and toantes, sung together with the shaking of the maracá, are key pieces to understanding about this identity. I analyze how ins built a tradition of knowledge that made possible the integration of various family groups around the Serra do Macaco, which organized themselves for the claim of indigenous identity. In the text, I also analyze, more closely, the part of the territory that is not yet regularized, called locally 'Área Nova' (New Area).
\end{abstract}

\section{KEYWORDS}

Kapinawá identity; Ritual network; Knowledge tradition.

\section{NOVENAS, SAMBAS E TORÉS: RÉSEAU RITUEL, TRADITION DE CONNAISSANCE ET IDENTITÉ INDIGÈNE} KAPINAWÁ

\section{RÉSUMÉ}

\footnotetext{
${ }^{1}$ Doutora em antropologia pela Universidade Federal de Pernambuco. Integra o Núcleo de Estudos e Pesquisa sobre Etnicidade (NEPE/UFPE) e Grupo de Estudos em Território e Identidade (GETI/UFPB). E-mail: laraerendira@yahoo.com.br.
} 
Cet article est le résultat de mes recherches de maîtrise en anthropologie à l'Université fédérale de Paraíba (2012-2014). Je présente ici la discussion de la thèse qui reflète comment les rituels ont permis la construction de réseaux sociaux et la constitution du sentiment d'appartenance ethnique chez les Kapinawá. Les mémoires et les significations donnés aux neuvaines et aux benditos chantés là-bas, les sambas et sambas de coco, qui donnent le rythme des pieds, et le toré et les toantes, chantés ensemble avec la maraca, sont des éléments clés pour comprendre cette identité. J'analyse comment se construit une tradition de connaissance qui a permis l'intégration des différents groupes familiaux autour de la Serra do Macaco, organisés par la revendication de l'identité indigène. Dans le texte, j'analyse de plus près la partie du territoire qui n'est pas encore régularisée, appelée localement «Nouvelle Aire».

\section{MOT-CLÉs}

Identité Kapinawá; Réseaux rituels; Tradition de connaissance.

\section{NOVENAS, SAMBASE TORÉS: RED RITUAL, TRADICIÓN DE CONOCIMIENTO E IDENTIDAD INDÍGENA KAPINAWÁ}

\section{RESUMEN}

El trabajo presentado en este artículo es el resultado de una investigación desarrollada durante la maestría en antropología de la Universidad Federal de Paraíba (2012-2014). Aquí presento parte de la discusión de la disertación que refleja cómo los rituales permitieron la construcción de redes y la consecuente constitución del sentido de pertenencia étnica entre los Kapinawá. Los recuerdos y significados que se le dan a las fiestas de novenas y a los benditos que allí se cantan, a las sambas y sambas de coco, que dan el ritmo del golpeteo de los pies, y al toré y toantes, cantados junto con el batir de la maraca, son piezas clave en el entendimiento de esta identidad. Analizo cómo se construye una tradición de conocimiento que permitió la integración de los diversos grupos familiares alrededor de la Serra do Macaco, que se organizaron para reivindicar su identidad indígena. En el texto también analizo, de manera más próxima, la parte del territorio que aún no está regularizada, denominada localmente "Área Nueva".

\section{PALABRAS CLAVE}

Identidad Kapinawá; Red ritual; Tradición de conocimento. 


\section{INTRODUÇÃO}

Aprendi com os Kapinawá, povo indígena que habita o semiárido pernambucano, como ritual e identidade indígena estão fortemente imbricados. Iniciei minha atuação no território em 2011, num contexto em que os indígenas promoviam a retomada da sede de uma fazenda que invadira seu território, na década de 1980. A partir daí, comecei a perceber como as memórias e sentidos dados às novenas e aos benditos aí cantados, a os sambas de coco e sambas, que dão o ritmo da batida dos pés, e ao toré e toantes entoados junto ao chacoalhar do maracá, são peças chaves na compreensão dessa identidade.

É importante compreender que a construção dessa "identidade kapinawá" não foi algo unívoco e uniforme. Ao longo dos últimos 30 anos, grupos familiares diversos foram se reconhecendo enquanto indígenas kapinawá em momentos distintos e as redes rituais tiveram papel fundamental nesse processo.

Essas diferentes dinâmicas de autorreconhecimento dos grupos familiares são nomeadas localmente, de forma que separam o território em três áreas, de acordo com o momento de organização social dos grupos familiares pelo reconhecimento da identidade étnica. Nesse sentido, existem: a Área Demarcada - Terra Indígena (TI) regularizada -, que tem o processo de organização e luta pela terra datado de fins da década de 1970; a Área Nova, que inicia seu processo de organização no fim da década de 1990; e, por fim, alguns agrupamentos familiares que começam a se organizar já em fins da primeira década dos anos 2000, as chamadas Aldeias de Ibimirim.

\section{MAPA 1 - TERRITÓRIO INDíGENA KAPINAWÁ}

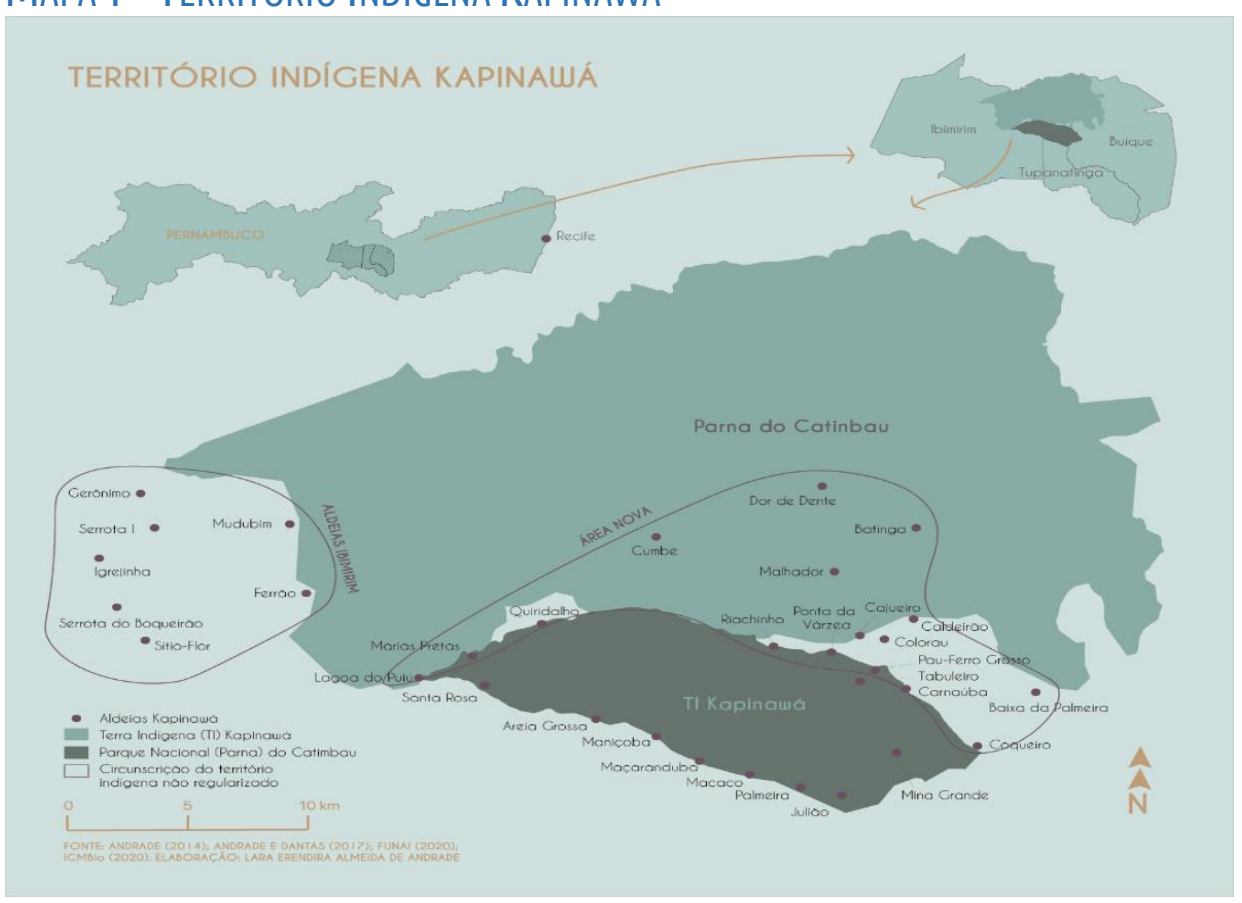


O objetivo particular deste artigo é refletir como os rituais praticados - trato particularmente da novena, do samba de coco e do toré - possibilitaram a construção de redes sociais e a consequente constituição do sentido de pertencimento étnico entre os Kapinawá.

O argumento central é que há uma rede de relações entre as famílias de diversas aldeias kapinawá. Tal rede se constitui a partir das alianças formadas pelo parentesco e toma corpo a partir da circulação de pessoas e grupos, entre as localidades que conformam o atual território indígena, para participação nos rituais acima elencados. A constituição dessa rede foi fundamental na construção das alianças políticas, dentro do contexto da organização étnica como indígenas Kapinawá, na conjuntura política particular de reivindicação da identidade indígena entre os anos 1980 e 2010.

No texto, trabalho de forma mais atenta a parte do território chamada da Área Nova. Para tanto, divido o artigo apresentando, inicialmente, o referencial teórico que ajuda a olhar esse contexto, em seguida, situo brevemente os movimentos de organização identitária kapinawá e, ao final, trato de cada um dos rituais já mencionados.

\title{
REDE, RITUAL, PARENTESCO E IDENTIDADE
}

No meu entendimento, o parentesco é um componente fundamental para a compreensão dessas dinâmicas rituais e identitárias. É no âmbito do grupo doméstico que são construídos os primeiros sentidos de pertencimento, são vivenciados valores, as pessoas participam dos primeiros rituais, etc. Trabalho com a ideia de "grupo doméstico flexível" definida por Wilk (1984)² e problematizada por Mura e Barbosa da Silva (2011):

\begin{abstract}
"[...] embora seus integrantes continuem cooperando entre si em algumas tarefas e estejam voltados a prover a unidade doméstica como um todo, podem também desenvolver atividades diferenciadas entre si (como envolver-se no comércio ou em trabalhos assalariados), fazendo com que cada unidade habitacional possa estabelecer estratégias de ação específicas, com certa autonomia [...] Wilk centra-se sobretudo nos aspectos econômicos e, assim, a definição de household limita-se a salientar a produção e a distribuição de bens materiais como fatores determinantes. A nós, parece-nos oportuno ampliar as características que definiriam as unidades, abrangendo a organização de aspectos imateriais - como conhecimentos, valores,
\end{abstract}

\footnotetext{
2 Wilk (1984) diz que um dos elementos básicos do conceito clássico de grupo doméstico (household), a corresidência, deve ser assinalado apenas como uma das atividades que o grupo doméstico desempenha; em alguns casos faria mais sentido observar outras atividades desempenhadas pelo grupo. Ele dá o exemplo dos antropólogos que trabalham na América Latina e no Caribe, onde é muito comum observar grupos que comem juntos, trabalham juntos, compartilham a criação dos filhos e outras atividades domésticas, mas objetivamente, vivem em casas separadas (cf. WILK, 1984, p.223). Assim, sua designação de grupo doméstico (household) se constrói muito mais pensando nas atividades de produção e distribuição do que na de corresidência. Ele formula a ideia de "grupo doméstico agregado" (household cluster), quando o grupo doméstico é formado de mais de uma "habitação" (dwelling). Desta categoria se desdobra ainda a ideia de "grupo doméstico flexível" (household cluster loose), na qual existiriam atividades diversificadas e autônomas entre as unidades habitacionais.
} 
lógicas educacionais, emoções e afetos, mas, também cargos e papéis sociais. Para tal propósito, além da produção e da distribuição, são também importantes a aquisição e a organização social de todos os elementos culturais e materiais à disposição do grupo" (MURA, BARBOSA DA SILVA, 2011, p. 99 e 100).

O grupo doméstico configura uma família extensa de três gerações: avós, pais e filhos. Ao longo do texto, em vez de trabalhar com a categoria analítica de grupo doméstico, trabalharei com a categoria local de "família"3.

Busco evidenciar como os rituais se constituem como elementos que delimitam os conteúdos ideativos da comunidade e das redes sociais existentes, que vão formando uma tradição de conhecimento (BARTH, 1987; 2000) ao longo do tempo, o que permitiu aos agrupamentos familiares se organizarem socialmente em torno da identidade étnica kapinawá. Considero a construção dessa tradição de conhecimento situada no contexto composto de diversas correntes de tradições culturais (BARTH, 2000), aqui levadas em conta as demais etnias indígenas das bacias dos rios Ipanema e Moxotó, onde se situa o Território Indígena, bem como os "regionais", pensando especificamente no contexto local em que estão inseridos.

Reflito principalmente com base nas formulações de Barth $(1987,2000,2005)$ e em autores que também analisam, a partir dele, os contextos etnográficos da região. Foram fundamentais, nesse sentido, as pesquisas de Pereira $(2004 ; 2011)$ e Albuquerque (2005, 2008, 2009), que trabalham com a conformação dessa tradição de conhecimento no mesmo contexto dessa pesquisa, focando o estudo na aldeia Mina Grande, centro político do território. Além desses, também C. Mura (2013), Mura e Barbosa da Silva (2011) e Mura, Palitot e Marques (2015) ilustram essa percepção, respectivamente, a partir dos contextos dos Pankararu (PE) e Tabajara (PB). Esse último conjunto de autores, assim como eu, consideram a centralidade da categoria de grupo doméstico na compreensão dos processos organizativos locais. A intenção aqui é perceber como se dá a organização social da cultura através da organização dos fluxos culturais (BARTH, 1987; 2000; 2005; HANNERZ, 1997), perceber essa cultura mais do que em termos genéricos, pensá-la como um processo de construção de significados e de conhecimento.

Barth $(1987 ; 2000)$ define a noção de tradição de conhecimento gestada com base na experiência das pessoas. Busco construir minha narrativa nesse sentido, a partir da experiência das famílias, centrada no âmbito doméstico e nas redes de relacionamentos

\footnotetext{
${ }^{3}$ É importante ressaltar que o termo família também é utilizado localmente com outros sentidos que não só o equivalente ao do grupo doméstico. Ele é utilizado, por exemplo, para designar a família conjugal ou, ainda, num sentido amplo e mais difuso que se aproxima à ideia de linhagens. Tratei de forma mais detida essas questões em minha dissertação. Ver Andrade (2014). Porém, ao longo deste artigo, quando me referir à ideia de família estarei tratando especificamente do que foi posto ao abordar o grupo doméstico.
} 
entre as aldeias ${ }^{4}$. Apoiada pela ideia de Barnes (1987), que destaca o conceito de rede social como um instrumento analítico importante para entender a política local, penso na rede constituída entre as famílias e comunidades como uma teia que envolve relações rituais, econômicas e políticas. Conforme já mencionado, considerarei as redes formadas pelas novenas, sambas de coco e pelo toré.

\section{OS KAPINAWÁ}

O povo indígena Kapinawá tem uma população de cerca de 2.500 indivíduos (ANDRADE; DANTAS, 2017). Seu território está situado em três municípios pernambucanos, na transição do agreste para o sertão do estado: Buíque, Tupanatinga e Ibimirim. Atualmente, o território Kapinawá conta com cerca de trinta aldeias, a maioria delas situadas no entorno da Serra do Macaco e ao longo dos dois principais riachos que cortam o território: o Riacho do Macaco e o Riacho do Catimbau.

Entre o final da década de 1970 e meados da década de 1980, as famílias que habitavam a região da atual aldeia Mina Grande sofreram forte investida de grileiros e fazendeiros sobre as terras que ocupavam. Esse conflito marca o processo de organização local em torno da identidade étnica e a reivindicação, junto à Fundação Nacional do Índio (FUNAI), da regularização fundiária.

Esse processo de reivindicação da identidade indígena, pelo qual vários outros grupos passaram na região ao longo de todo o século XX, foi chamado por Oliveira (1999) de processo de territorialização. Ele compreende a ideia de um amplo movimento de reorganização social das famílias que implica, segundo o autor, quatro principais movimentos: um primeiro de "criação de uma nova unidade sociocultural, mediante o estabelecimento de uma identidade étnica diferenciadora"; um segundo que organiza "mecanismos políticos especializados"; um terceiro movimento de "redefinição do controle social sobre os recursos ambientais"; e, por fim, o que me interessa neste artigo, um movimento de "reelaboração da cultura e da relação com o passado" (OLIVEIRA, 1999, p. 20).

Entre os então autodenominados Kapinawá, um dos processos desencadeados nesse contexto foi o de aprender a dançar o toré, para assim cumprir com uma espécie de "modelo de indianidade" genérica esperada dos índios do Nordeste, imposto no tempo do Serviço de Proteção ao Índio (SPI) e que tinha dois componentes determinantes para o

\footnotetext{
${ }^{4}$ É importante ressaltar a diferença entre algumas categorias que utilizarei ao longo deste artigo. A junção de alguns grupos domésticos conforma agrupamentos familiares geograficamente delineados. Para referência a essa unidade organizacional trabalharei neste artigo, assim como na dissertação (ANDRADE, 2014), com o termo comunidade política local, ou simplesmente comunidade, e para o momento posterior ao da organização local em torno da identidade indígena, com a ideia da aldeia, como atribuído localmente.
} 
reconhecimento do órgão indigenista oficial: a dança do toré e a criação de uma estrutura política composta por cacique, pajé e chefe de posto (OLIVEIRA, 1999).

Depois de muita pressão junto ao órgão indigenista oficial, os já autodenominados Kapinawá conseguiram que, no ano de 1984, fosse realizado um estudo para identificação do território como indígena. Porém, foi apenas no ano de 1998 que a FUNAl deu prosseguimento aos processos legais e homologou a terra com os limites identificados na década de 1980, somando 12.403ha.

No fim da década de 1990, outros agrupamentos familiares, principalmente situados ao norte da T.I. regularizada, começaram a se organizar também em torno da identidade indígena kapinawá e pela regularização do território, a mencionada Área Nova. No início dos anos 2000, esses Kapinawá são "surpreendidos" com a criação de uma unidade de conservação englobando o território habitado: o Parque Nacional do Catimbau. O Parna do Catimbau foi criado pelo Decreto $n^{\circ}$ 4.340, de 22 de agosto de 2002, e tem o "objetivo de preservar os ecossistemas naturais existentes, possibilitando a realização de pesquisas científicas e o desenvolvimento de atividades de educação ambiental e turismo ecológico", uma unidade de conservação integral, que juridicamente não permite a permanência de pessoas em seu interior.

Ao longo dessas quase duas décadas de criação do Parque, ocorreram vários conflitos entre agentes do Instituto Chico Mendes de Conservação da Biodiversidade (ICMBio) e famílias Kapinawá. Instaurou-se um clima de insegurança entre as famílias que habitam essa região em razão da ameaça de ter que sair de seu território.

Esse clima se intensificou no ano de 2011 quando um dos fazendeiros afirmou que iria criar, na sede de sua fazenda, uma pousada para o turismo ecológico. A notícia se espalhou pela região levando os indígenas a ocuparem a sede dessa fazenda em agosto do mesmo ano. Essa mobilização está situada dentro de um contexto maior de reivindicação de ampliação da T.I. Kapinawá, que data de mais de uma década. Na época, a fazenda já havia sido abandonada há mais de dez anos pelo proprietário, e famílias kapinawá a reocuparam, usando para plantio e criação de animais. Foi no referido período da retomada que iniciei minhas pesquisas nesse contexto, inicialmente o mestrado 2012-2014 (ANDRADE, 2014) e, em seguida, o doutorado 2016-2020 (ANDRADE, 2020).

Ao longo desse artigo irei me basear, sobretudo, nas entrevistas que realizei durante a pesquisa de mestrado com os seguintes interlocutores: da aldeia Mina Grande, Seu Zé de Caetano, Lilia e seu Arlindo; das aldeias que ficam no limite norte da T.I., Seu Cícero, Seu Pipiu do Pau Ferro Grosso e Sesser do Quiridalho; da Área Nova, Dona Lia, Dona Helena da aldeia Malhador, Dona Marieta da aldeia Colorau e Seu Zé Firmino da aldeia Caldeirão.

\section{REDE RITUAL KAPINAWÁ}


Meu argumento principal é que os rituais são um dos principais eixos de articulação e sociabilidade nas redes de relações entre as famílias kapinawá. A partir da observação dos fluxos dessas redes, é possível acompanhar os caminhos de cada um dos movimentos de autoidentificação como indígena.

Pereira (2011), ao falar das práticas rituais e de música entre os Kapinawá da aldeia Mina Grande, chama a atenção para o fato de que os gêneros musicais que são entoados provêm de "tradições e situações musicais distintas" que, por sua vez, se vinculam às tradições de conhecimento mais amplas às quais se relacionam:

"Nesta perspectiva, com os benditos, José Caetano, Arlindo e Maria [Lilia] nos levam às suas formações (e do grupo) católicas, aos repertórios aprendidos com pais e avós, aos serviços e missas na cidade próxima de Buíque, ou na capela de São Sebastião quando Mina Grande é visitada pelo padre. Esses "benditos antigos" dão conta de pequeno panteão católico, em particular Jesus Cristo, Nossa Senhora, São José e São Sebastião. Com os toantes, de aquisição recente, nos levam para as assembleias indígenas, para as mobilizações políticas, para os "levantamentos de aldeias" que unem, através de lideranças (no caso, especializadas no ritual do toré e tudo que implica), grupos em circuitos de relação de amplo espectro, ultrapassando microrregiões e, por vezes, alcançando o nível nacional. Com os sambas, sambas de coco, nos levam para redes de sociabilidade que unem familiares - próximos e distantes -, vizinhos e conterrâneos às festas e levantamentos de casas e pisadas de terreiro e chão" (PEREIRA, 2011, p. 593 e 594).

No mapa a seguir, represento essas redes de relacionamentos entre as aldeias, que não têm uma fronteira rígida entre si, e aldeias como a Ponta da Vargem e a Mina Grande funcionam como localidades articuladoras das demais. Como um nó de conexão entre esses círculos de articulação, estabelecem mais de um círculo de relações, percebido pela intersecção de mais de dois arcos, como se vê no referido mapa.

Evidenciarei os movimentos das pessoas e grupos a partir do aprofundamento das informações apresentadas no Mapa 2 e em mapas com vetores que representam esses deslocamentos. 


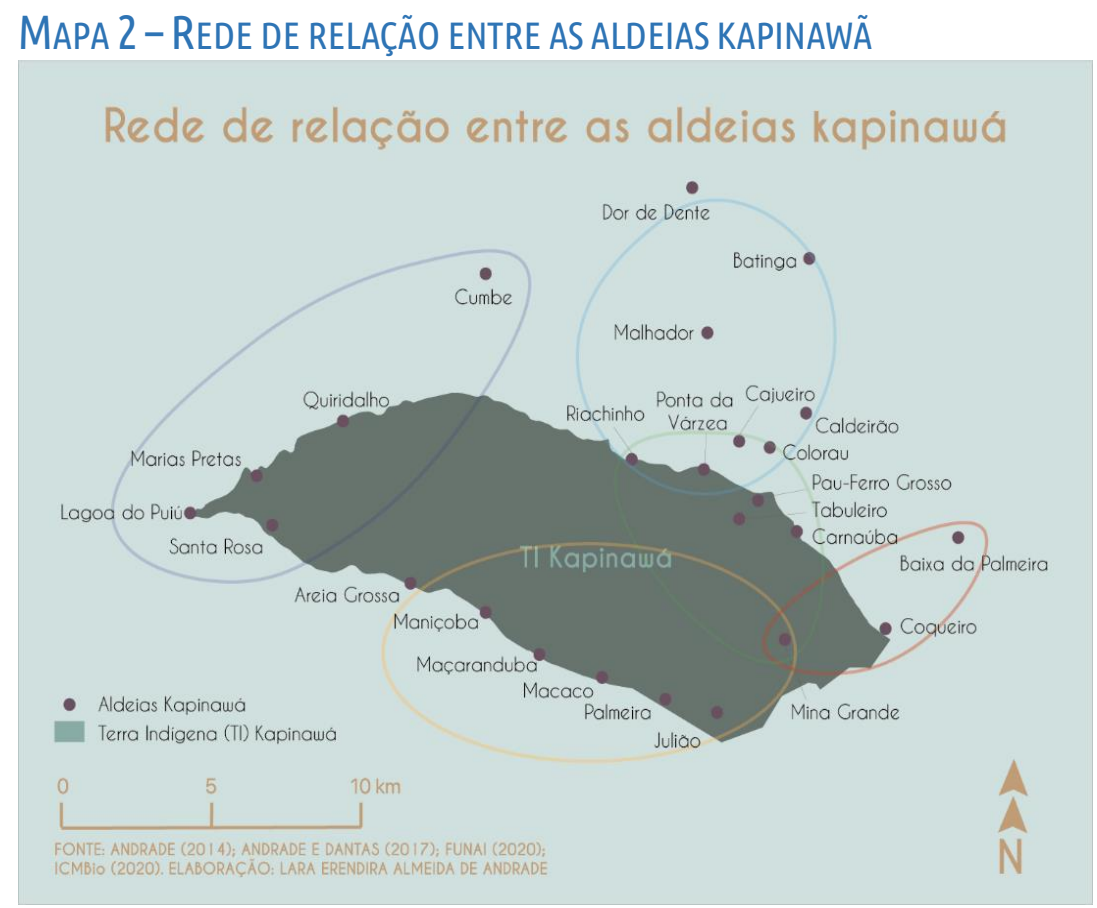

\section{AS NOVENAS}

Conforme mencionado por Pereira (2011), o ritual da novena nos remete a uma corrente de tradição que é, de forma muito genérica, conhecida como catolicismo popular. Um conhecimento aprendido com pais e avós a partir de suas participações nas missas das cidades próximas e também naquelas celebradas especificamente nas aldeias. No caso aqui apresentado, é interessante perceber como esse ritual ganha um corpo muito particular entre os Kapinawá que tem muito mais a ver com as relações de parentesco e dinâmicas identitárias, fugindo, assim, aos dogmas e hierarquias da instituição católica propriamente dita.

A ideia de que essa corrente de tradição tomou um contorno específico no caso aqui estudado pode ser percebido a partir de dois processos de organização social local desse conhecimento que tratarei a seguir como novena para os santos de casa e "etnificação" das novenas.

A novena, como o próprio nome dá a entender, é realizada ao longo de nove dias. Segundo narram localmente, ela é iniciada com a reza do terço, na qual são feitas as orações do Pai Nosso, Creio em Deus Pai, Salve Rainha, Senhor Deus. Ao final do terço, são entoados benditos. No momento seguinte, é incorporada à banda de pífanos, composta de dois tocadores de pífano, um de zabumba e um de caixa. A banda toca em frente à imagem do santo, e os músicos, tocando e dançando, se entrelaçam, mudando de lugares. Por fim, a imagem do santo é levada, junto à banda de pífano e aos participantes, para dar três voltas em torno da casa - ou na capela, se ela existir na localidade - e então é colocada de volta em seu lugar. 
A ideia de que a novena é uma festa para santo de casa nos mostra que ela tem um caráter doméstico. Ao longo da pesquisa, toda vez que falávamos das novenas, a maioria das pessoas não lembrava exatamente para que santo se rezava, mas sim a família responsável por sua realização. Somente na Área Nova, quatro das dezesseis aldeias contam com a cerimônia. São elas: aldeia Quiridalho - novena de Santa Terezinha, de 24 de setembro a 01 de outubro; aldeia Ponta da Várzea - novena de Nossa Senhora Aparecida de 04 a 12 de outubro; aldeia Caldeirão - novena de Nossa Senhora das Graças de 11 a 19 de novembro; e aldeia Malhador - novena de Nossa Senhora de Guadalupe a partir de 12 de dezembro.

Nas três citações a seguir, o argumento apresentado acima pode ser acompanhado na fala de três anciãos das aldeias da Área Nova: Zé Firmino, Dona Lia e Dona Marieta:

Maria, qual era os santos que festejava aqui? Novena tinha a de mãe. Tinha a de Zé Cariri para acolá [aldeia Colorau]. Quando terminava aqui nós íamos pra lá e rezávamos. [outros falam: tinha o finado Mema, que morava na aldeia Malhador]. [...] Tocava com pife e zabumba, era um menino ali no Colorau, ainda hoje tem. Quando eu era novinho tinha um bocado de gente, que tocava e que assistia (Seu Zé Firmino, Aldeia Caldeirão, maio de 2013).

Tem [novena] também minha filha, é bonito. Naquele tempo que Zé Cariri (Colorau) era vivo, aquele Tio Mema (Malhador), tinha Antônio Carlos (Caldeirão) [...] Esses Cariri tocavam zabumba, faziam as novenas. Elas aconteciam mês de setembro, outubro. Era festa pra todo santo, vinha muita gente, a casa enchia (Dona Lia, Aldeia Malhador, maio de 2013).

Conheci muita novena. Meu pai era tocador de zabumba. Meu tio era Zé Cariri, primo de meu pai, tocava pife. Os Raimundo tudinho eram zabumbeiros, tocavam que fazia gosto. [...] Eles toda vida foram zabumbeiros, eu nasci e me criei em noite de festa, zabumba, novena, era muita diversão de zabumba, [...] O novenário era no São João, e então no mês de setembro festejar na casa da minha avó, na casa da minha tia Antônia que morava no Caldeirão, era só pra festejar, mas não sei que santo era (Dona Marieta, Aldeia Colorau, maio de 2013).

Optei por mostrar estas três descrições das novenas, pois deixam entrever a circulação de pessoas para a participação das novenas na Área Nova. Mostram como os laços familiares são movimentados nas visitas para a participação nas novenas. As pessoas do Caldeirão iam para a Ponta da Vargem e Malhador; as do Malhador, para Caldeirão e Ponta da Vargem; as do Colorau, para a Ponta da Vargem e Caldeirão; da Ponta da Vargem iam para o Caldeirão e também para a Mina Grande. As novenas sempre aconteciam nas casas daqueles que eram responsáveis pela sua realização. 


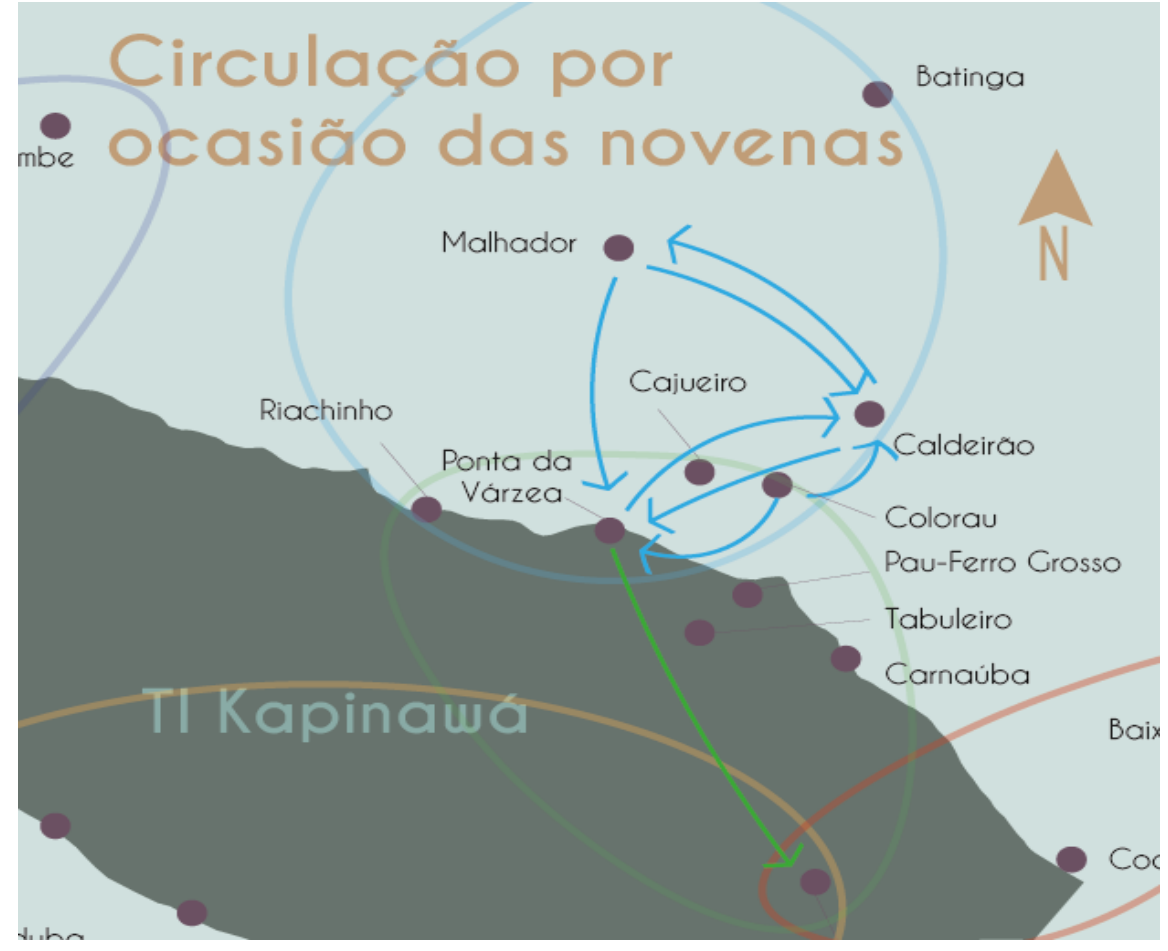

A partir da década de 1980, com o processo de organização social para a reivindicação da identidade indígena, ocorre uma releitura local das antigas novenas, uma espécie de "etnificação" da celebração, de início de celebração aos "santos protetores dos índios". Dito de outra forma, as famílias que estavam reivindicando a identidade indígena "selecionam" a novena como um dos sinais diacríticos de sua indianidade, um dos elementos de conformação da fronteira étnica, do ser Kapinawá.

Há dois casos que expressam bem essa ideia. O primeiro deles ocorre na Mina Grande, nos idos de 1980, período já mencionado de intensos conflitos territoriais. Zé de Caetano e Dona Lilia, dois especialistas em rituais dessa aldeia relatam que, antes do "Corte dos arames" , a única novena que era realizada na localidade ocorria no mês de maio: "era tempo para os santos de casa mesmo, santo mariano. Agora é na igreja, mas nessa época não tinha não". Ao falar de como acontecia no passado e hoje, são mencionadas as casas por onde o novenário passa: "a reza ficava principalmente em três casas: na casa de Vidali; na casa de Mané Chiquinha; e a casa de Caetano, pai de Germano".

Com o processo de luta pela terra mencionado no parágrafo anterior, há a inserção de novos atores políticos no contexto, a exemplo do Conselho Indigenista Missionário (Cimi) que começa a atuar na área somando o apoio da diocese. É nesse contexto que os moradores

\footnotetext{
5 "Corte dos arames" é como é chamado localmente o processo de luta pela terra de fins da década de 1970 e início dos anos 1980. Faz referência às diversas vezes que os Kapinawá cortaram os arames das cercas que os fazendeiros tentavam colocar em seu território.
} 
da Mina Grande são "apresentados" por Fábio Alves dos Santos, o Fabião - missionário do CIMI à época - a São Sebastião6 ${ }^{6}$, reconhecido por ser um santo guerreiro e mártir. A imagem e os sentidos de São Sebastião são reapropriadas pelos minagrandistas, ganhando uma conotação identitária, passando a ser conhecido como "o santo guerreiro, protetor dos índios"'7.

Nesse período, ergueram uma capela em nome do santo, que virou padroeiro da comunidade e símbolo de indianidade e proteção nesse processo de luta pela terra. A foto seguinte retrata o altar da capela, em 1986, onde visualizamos esse movimento: São Sebastião, recém-incorporado ao panteão de santos da comunidade, com os antigos conhecidos São João, ladeado de duas imagens de Nossa Senhora, uma pequena imagem de Jesus crucificado, e a imagem do Padre Cícero.

Outro processo de etnificação das novenas aconteceu no contexto de reivindicação da identidade indígena na Área Nova, já nos anos 2010. Na aldeia Malhador, começaram a realizar a novena para Nossa Senhora de Guadalupe. Os moradores fizeram uma grande construção em formato circular coberta de palha, que chamaram de oca. Esse espaço era utilizado para fazer os torés, e também para a realização da novena. Já no ano de 2013, em regime de mutirão, construíram uma capela para Nossa Senhora de Guadalupe, específica para a festa, que começou a ser realizada por se tratar da santa indígena, segundo contam.

\section{Foto 1 - Altar da Capela de São Sebastião, Mina Grande, em 1986}

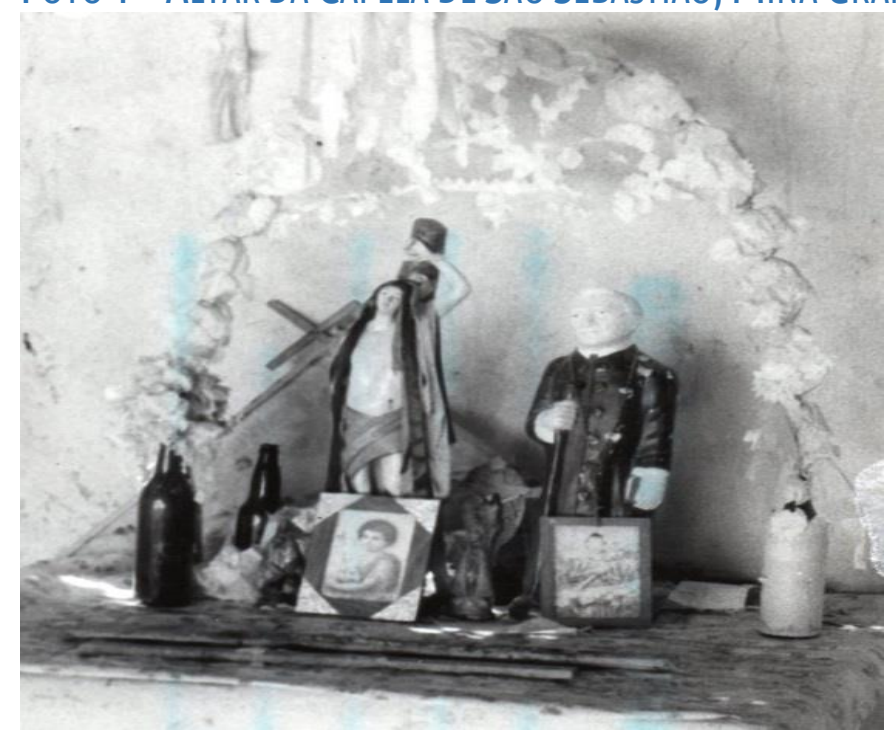

Fonte: Acervo do Cimi, foto de Zé Karajá

\footnotetext{
${ }^{6}$ Essa informação, a inserção de São Sebastião na Mina Grande, tanto foi mencionada por meus interlocutores na Mina Grande quanto foi recontada pelo próprio Fabião em entrevista que realizei com ele em agosto de 2013.

${ }^{7}$ Não tenho maiores informações sobre esse processo, mas possivelmente essa analogia de São Sebastião como santo protetor de índios é feita em virtude da iconografia do santo que é associada a um arco e flecha.
} 
Fotos 2 e 3 - Altar e Capela de Nossa Senhora da Guadalupe no Malhador, 2014
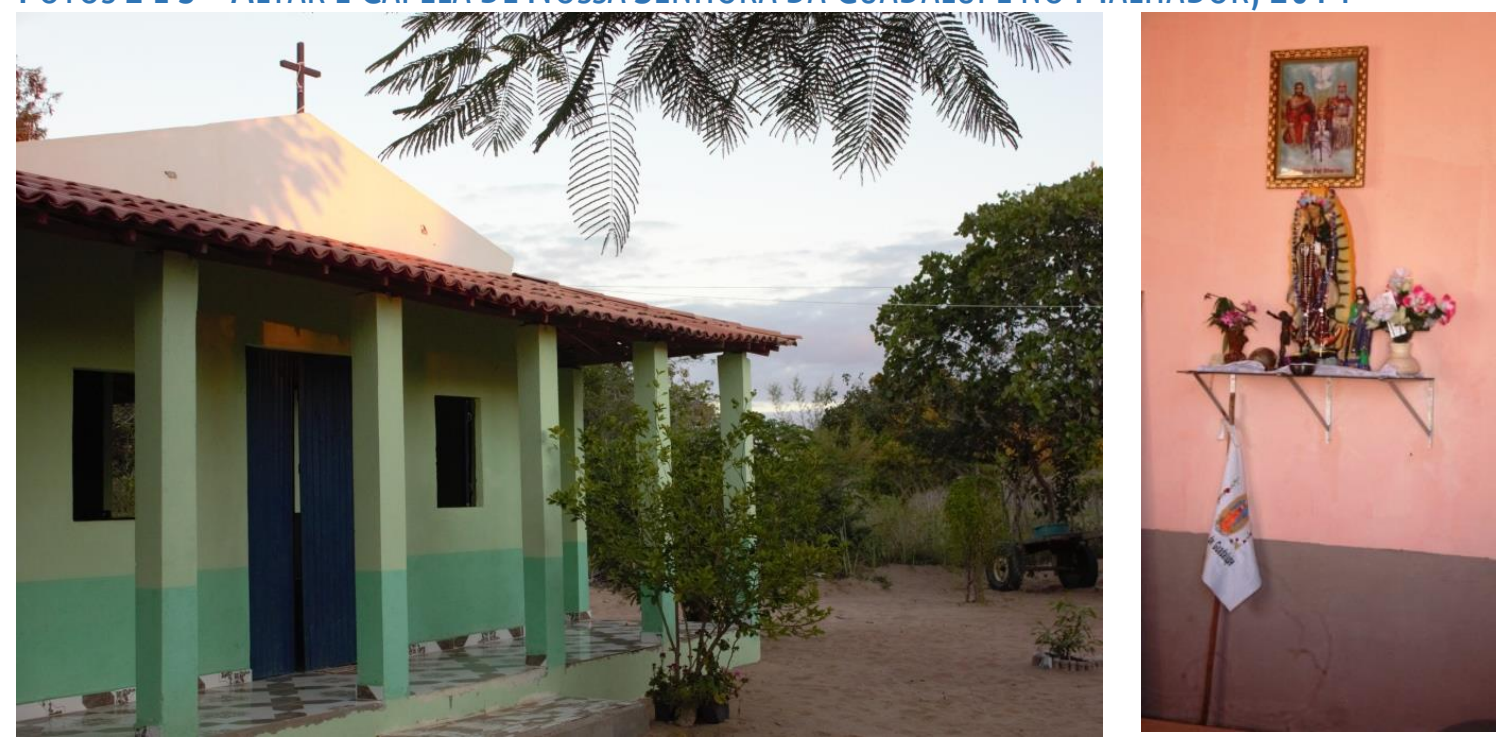

\section{O SAMBA DE COCO}

Outra corrente de tradição cultural que compõe os rituais da tradição de conhecimento Kapinawá é o samba de coco. Assim como as novenas, o samba de coco é uma prática que ultrapassa os limites desse grupo. É um festejo tanto entre os grupos urbanos e rurais dessa região quanto, por exemplo, do povo indígena Xukuru, que tem seu território situado em município vizinho.

Também como a novena, o samba de coco é rememorado pelas famílias dos arredores da Serra do Macaco como prática "que sempre existiu". Sendo praticado tanto para aterrar o chão das casas de taipa quanto como festejo em ocasiões específicas. O samba de coco, realizado na chamada "tapagem" (ação de preencher a ossatura da casa, como veremos em seguida) das casas de taipa, é momento privilegiado de socialização da comunidade. Tudo começa já no momento de busca da matéria prima: o barro é coletado próximo às residências, no local de "cavar o barro"; a madeira, tirada na caatinga. Tudo carregado pelas próprias pessoas ou por animal. "O samba já começava na hora de mexer o barro", relatam.

Para a construção da casa não é necessário um número muito grande de pessoas. Indivíduos da própria comunidade são convidados para ajudar: "Era só o pai de família e os filhos. Chamavam os vizinhos também". Entre as pessoas convidadas para construir a habitação, há um responsável, pago para montar a estrutura, chamado de "mestre" ou "chefe". Fica a cargo dele fazer a armação de madeira da morada, cavar os buracos, trançar as ripas de madeira e o mais importante, colocar o esteio ou caibro - mastro de madeira principal que dá sustentação ao telhado. Se o telhado for de palha, o trabalho está terminado. Se for de telha, é necessário colocar ripas de madeira perpendiculares a ele. 
No momento seguinte, as pessoas colocam o barro entre as ripas de madeira, subindo assim as paredes, a tapagem da casa. Posteriormente, vem o telhado. Por fim, é feito o chão da casa, apilado ${ }^{8}$ com o samba de coco: o povo "mete o pé":

Uma casa dessa o caba tapava em um dia, e de noite nós íamos dançar o samba de coco, dançava animado, vinha o povo de perto, não era muito de longe não [...] daqui mesmo da Ponta da Vargem, do Colorau, de perto né, vinha gente do Pau Ferro (Zé Firmino, Aldeia Caldeirão, maio de 2013).

Como se vê, o instante de "bater o chão" da casa marca um segundo momento desse processo, quando ele deixa de ser apenas do âmbito doméstico e passa a ser uma celebração maior, que envolve não só pessoas da aldeia, mas também de outras próximas, com as quais existe uma relação.

Algo semelhante acontece com o trabalho "em batalhão", assim como na tapagem das casas. Esse trabalho consiste num trabalho coletivo, mas aqui com o intuito de fazer grandes plantações. O dono da roça faz o convite que, como para a construção da casa, se estende a familiares e vizinhos. O trabalho em batalhão exige um pouco mais de mão de obra, podendo chegar a mais de duas dezenas de pessoas. Ao final do período de trabalho para levantar a roça, o anfitrião oferece um porco ou bode para alimentar os que foram contribuir e, em algumas ocasiões, o momento é finalizado também com o samba de coco.

De acordo com as narrativas de meus interlocutores sobre o período anterior ao "levantamento da aldeia", tanto o samba de coco realizado após a tapagem das casas, quanto o realizado após o trabalho "em batalhão", evidencia como funcionavam os processos colaborativos: não somente no âmbito do grupo doméstico, mas também no interior da aldeia, assim como entre aldeias distintas, em grande medida, baseado no parentesco.

Quando realizado como festividade, o samba de coco é momento privilegiado de socialização entre as diversas aldeias, assim como as novenas, fazendo circular pessoas dentro do território mais amplo. Todos os meus interlocutores narram como iam de uma localidade para outra para participar dessa celebração. Também fazem alusão ao samba de coco em ocasiões, alguns se referem a ele ocorrendo no fim das novenas, após a banda de pífanos. Outros ainda falam dele tocado nas festas de São João, que eram realizadas em dias de fogueira ou de quinze em quinze dias.

Essas festividades ganham, dessa forma, duas dimensões: uma mais doméstica e comunitária, do cotidiano, quando se juntam apenas as pessoas de determinada localidade, e outra que reúne pessoas de aldeias distintas. As aldeias que atraem pessoas de lugares

\footnotetext{
8 "Apilar" é o termo usado localmente para descrever a ação pisar/bater o barro que compõe o chão da casa de taipa até que ele esteja firme e plano.

9 Termo que indica o processo de reorganização étnica e reconhecimento político de um povo indígena.
} 
diferentes geralmente são aquelas que tem "cantadores profissionais", termo utilizado localmente para designar aqueles reconhecidos como bons cantadores. Meus interlocutores citam os sambas de coco que atraíam mais gente:

(1) A Mina Grande, os cantadores eram "esses mais velhos, o finado Vidali, pai do ex-cacique Santo; João Mariano e Maria de João de Mariano, pais de Lilia; e João Bernardino, pai do também ex-cacique Zé Bernardo" (Seu Arlindo).

(2) O Caldeirão também era conhecido em função dos Carlos, uma família de cantadores, onde Antônio Carlos e João Carlos eram os mais conhecidos: "aqui não fosse o povo da Mina Grande era esse pessoal dos Carlos no samba de coco, na casa do finado Manezim tinha um, todo fim de semana" (filho de Pipiu).

(3) Por fim, também as festas na Ponta da Vargem eram conhecidas, onde iam cantar os Carlos, mas também um cantador de samba de coco conhecido na região do Catimbau, chamado de João Rosa. O filho de Pipiu diz que "João Rosa era o rei do samba", e dona Lina Carlos narra esses caminhos dos cantadores: "João Carlos cantava no Caldeirão, na Ponta da Vargem, no Catimbau, no Brejinho, ele cantava mais João Rosa que vinha do Catimbau, pro lado do Joaquizinha, ali quase pro caminho da Serrinha".

As informações coletadas sobre as relações estabelecidas com o samba de coco ilustram bem a circulação na região. Seu Arlindo, que é da Mina Grande, fala que ia para sambas no Julião e no Macaco, e que também dançava nos arredores de sua localidade, Coqueiro, Ponta da Vargem, Tabuleiro, Pau Ferro Grosso, "mas no Colorau não ia não. Pronto, nós fomos em coco no Caldeirão, mas parece que a gente ia só dançar. O finado Vidali ia cantar coco lá. Não sei se João Mariano ia". Seu Cícero Frazão, que é do Pau Ferro Grosso, também fala por onde circulava: "dançava aqui na Ponta da Vargem e no Caldeirão, e na Mina Grande era difícil de eu ir". Mas a trajetória que melhor expressa essa circulação na região é a de Dona Helena, como fica evidente no trecho de fala a seguir:

O samba de coco? Era a profissão da gente. Nós mesmos cantávamos, um cantava, outro cantava, a família era toda cantadeira e toda dançadeira de samba de coco. Nós dançávamos quando chegava naquele dia da semana, a gente chamava aqueles vizinhos, "vamos dançar uma rodinha pra nós nos divertirmos", ai cantava e dançava. Nós também dançávamos no Riachinho, na Ponta da Vargem [...] Às vezes, ia assim, em novena de São João, aí quando terminava a novena cantava um samba de coco pra nos entreter. Pra esse samba na Ponta da Vargem ia gente era daqui, da região aqui da Ponta da Vargem, era de lá mesmo do Riachinho, só vinha assim de perto, da Mina Grande não vinha ninguém não. Vinha do Julião, vinha.

Do Caldeirão eu alcancei, que cantava samba de coco, primeiro era Antônio Carlos, o pai de João Carlos. Antônio Carlos era o cantador de samba profissional. Ai depois que Antônio Carlos morreu, quem cantava samba de coco na Ponta da Vargem era João Rosa. la dançar samba de coco lá com João Carlos.

E aqui na serra [do Macaco] também dancei muito samba de coco, o cantador aqui da serra, do Julião, Macaco, era Galdino, pai de Nero, primo de seu Arlindo. Galdino cantava lá para o Julião, minha mãe, o cunhado 
dela morava no Julião, e ela passava a semana todinha trabalhando lá, de serviço alugado para arrumar o pão. Nós dançávamos que a poeira tapava. O samba naquela época era pegado, era de dois, homem com mulher, pareia. Brincava a noite toda, eles cantavam a rodinha na parcela do toque do ganzá a gente fazia no pé. (Dona Helena, Aldeia Malhador, julho de 2013).

Essa fala de Dona Helena dá a dimensão dos circuitos formados para participação nos sambas e se relaciona também com sua história de vida. Ela nasceu no Riachinho, vizinho à Ponta da Vargem, mas seu pai era da região da Serra do Macaco, o que a liga àquela região. Além disso, casou-se com João Amâncio e foi morar no Malhador, o que a aproxima do Caldeirão. Aqui, nos reencontramos com o argumento inicial e lembramos que essas redes também são proporcionadas pelas relações de parentesco estabelecidas no território. 0 mapa a seguir ilustra esse movimento.

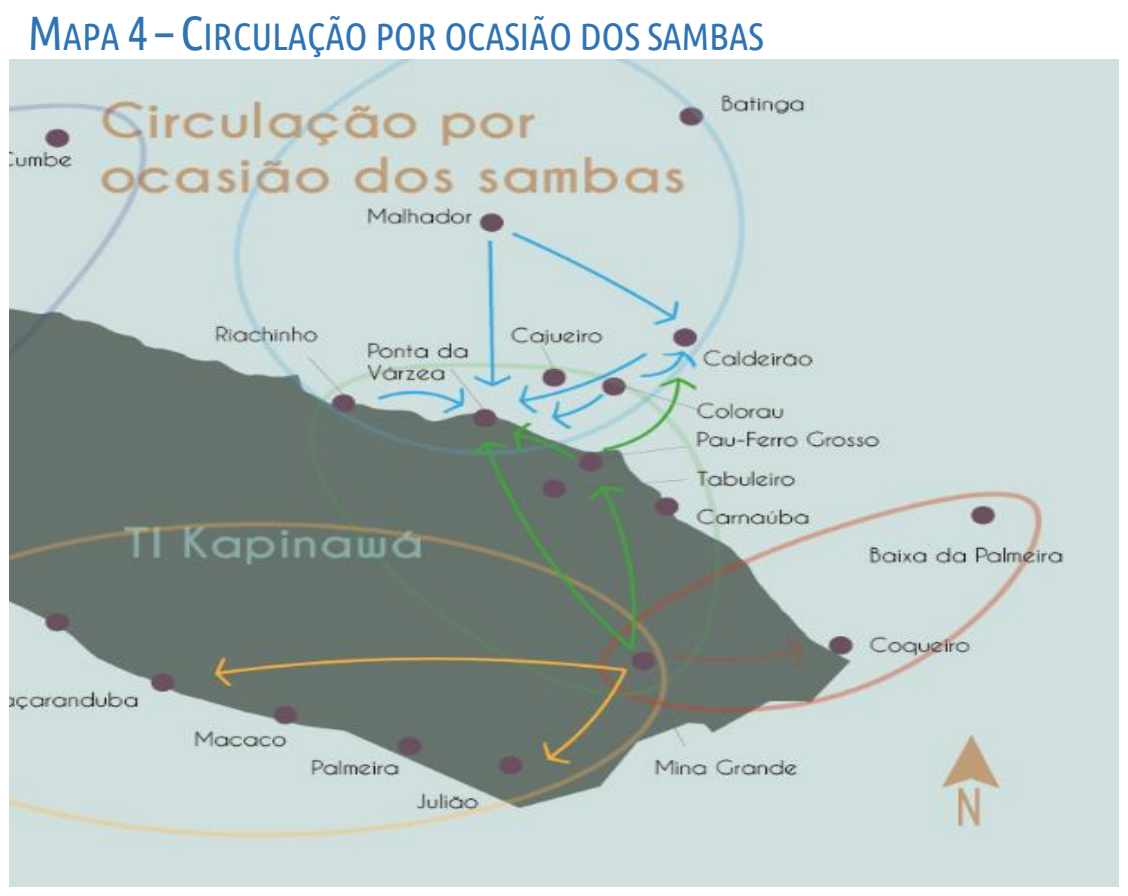

Como na novena, o samba de coco também passou por uma modificação desencadeada pelo movimento de organização das famílias dos arredores da Serra do Macaco, de reivindicação pela identidade indígena Kapinawá, o que acima chamei de processo de "etnificação". É assim que a prática do já antigo samba de coco é juntada ao toré recém-inserido, formando o toré-coco, que vou tratar no tópico seguinte.

\section{O TORÉ}

Diferente das novenas e dos sambas de coco, que são práticas ancestrais entre as famílias que começaram a se identificar como Kapinawá, o toré foi uma corrente de tradição 
cultural que se agregou à tradição Kapinawá a partir do momento de reivindicação da identidade indígena na década de 1970.

Como já mencionado, os povos que passaram pelo processo de reivindicar a identidade indígena ao longo do século XX adotaram um certo "modelo de indianidade". Esse processo de transformação local estava muito ligado à interlocução com o Estado, em função de uma expressão genérica esperada dos índios no Nordeste, formulada ainda nos tempos do Serviço de Proteção ao Índio (SPI). Entre esses elementos estava a reorganização política com a criação de uma estrutura centralizada formada por cacique e pajé, bem como a prática do toré como expressão ritual. Segundo Grunewald (2008),

"O toré e jurema são os dois principais ícones da indianidade nordestina. São elementos culturais que, embora não exclusivos das sociedades indígenas, codificam a autoctonia dos índios da região Nordeste do Brasil. O toré é uma tradição indígena de difícil demonstração substantiva por conta da variação semântica e das diversas formas de suas realizações práticas entre as sociedades indígenas e fora delas (1). Trata-se, a princípio, de uma dança ritual que consagra o grupo étnico. Não se pode, além disso, precisar uma origem do termo e até do ritual do toré pela ausência de narrativas coloniais a seu respeito. O Toré ganha visibilidade (e a relevância atual) a partir de um processo social que se inicia na primeira metade do século XX" (GRUNEWALD, 2008, p.43).

Ao inserir o toré nos rituais locais, ele foi muito rapidamente articulado às práticas locais já existentes. Nesse caminho, o toré foi "traduzido" nas cerimônias já conhecidas pelo grupo, de modo que também as suas práticas foram ganhando novas formas. Como já considerado em relação às novenas, o samba de coco passou por um processo de etnificação a ser visto (e "traduzido") como "coisa de índio", selecionado como sinal diacrítico na construção da identidade étnica pelas famílias locais.

Não irei me alongar no trato desses processos, pois foram densamente trabalhados em duas pesquisas anteriores a esta pelos autores já mencionados Albuquerque (2005, 2008, 2009) e Pereira $(2004,2011)$. Albuquerque $(2005)$ trata do assunto em sua dissertação, detendo sua atenção na conformação do toré-coco, no contexto específico de organização da Mina Grande:

\footnotetext{
"Ao unir-se ao toré, o samba-de-coco passa a ser reconhecido como uma tradição, não mais dos antigos apenas, mas ao ser incorporado ao toré, ganhou o status de tradição indígena, ao mesmo tempo presente e passado Kapinawá. De "brincadeira" o samba passa a representar uma tradição dos índios Kapinawá, e passa, deste modo, por algumas transformações, para Lilia, "O samba é um, o toré é outro, depois que inventemo o toré aí inventemo o samba-de-coco em toré também" (ALBUQUERQUE, 2005, p. 106)

"Uma constatação curiosa é a de que o canto e a dança do toré são elementos culturais importantíssimos, mas eles significativamente não representaram a grande novidade da emergência étnica kapinawá, já que, como visto, canto e dança estavam presentes nos benditos e no samba-de-coco" (ALBUQUERQUE, 2005, p. 150).
} 
Pereira (2004; 2011), por sua vez, dedicou dois artigos para o trato da etnomusicologia entre os gêneros musicais da Mina Grande, os benditos, sambas de coco e toantes, lançando olhar atento aos processos de entrelaçamento das correntes de tradição cultural. O autor classifica o "coco de toré" como um

\begin{abstract}
"gênero aparecido nas últimas décadas entre os Kapinawá em que a rítmica e divisão melódica dos cocos é fundida às poéticas dos toantes, sendo, na atualidade, uma das marcas de diferenciação do toré kapinawá frente ao dos demais grupos indígenas da região" (grifos no original) (PEREIRA, 2011, p. 594).
\end{abstract}

Como mencionado, os autores trabalham especificamente na Mina Grande; é precisamente nessa localidade que o samba de coco e o toré são traduzidos, em um contexto político particular de afirmação étnica daquela comunidade frente à tentativa de espólio de seu território. Desconfio que esse movimento de traduzir o samba para o toré (e o toré para o samba) tenha facilitado o processo de identificação com o complexo ritual do toré das comunidades que se organizam em momentos posteriores como Kapinawá.

Регеira (2011) chama atenção, ao evidenciar o repertório musical cantado durante um ritual na Mina Grande, que é composto não só de toantes mas também de gêneros já conhecidos pelos moradores da Mina Grande. O ritual surgido no contexto de mobilização política é, pois, uma composição que soa familiar àquelas comunidades, que começa com benditos e segue com sambas de coco, toantes e toré-coco.

Assim como aconteceu nas demais práticas, o toré é um ritual que proporciona a circulação entre as redes existentes. Foi ele que promoveu espaço para que as redes de circulação circunvizinhas extrapolassem os limites mais próximos e familiares, e se estabelecessem relações políticas com comunidades mais distantes no contexto do "Corte dos arames". Observemos como isso ocorre com o Quiridalho e a Mina Grande.

O toré começou a ser praticado no Quiridalho no contexto em que algumas pessoas da localidade foram em busca de cura no terreiro de seu Elias ${ }^{10}$, em Ibimirim, e acabaram seguindo suas doutrinas. Naquela ocasião, Seu Elias abriu dois terreiros que eram de responsabilidade dos "médiuns doutrinados"11 por ele: um no Quiridalho e outro em Santa Rosa, que tinham como guias, respectivamente, Antônio e Cazuza. Quando do

10 Os trabalhos realizados no terreiro de seu Elias são referenciados localmente tanto como "trabalho de índio", relacionado aos terreiros de toré, quanto aos trabalhos que usualmente se denominam como "umbanda". Seu Elias era Xukuru, especialista ritual, e desempenhou importante papel nas redes de emergência que se constituíram. Tinha um importante centro ritual em Ibimirim, um terreiro entre os distritos de Poço da Cruz e Boa Vista. Para mais informações sobre o ritual neste contexto indico Albuquerque (2005), que faz uma etnografia da conformação do ritual e das relações "trabalho indígena" e de "umbanda" neste contexto.

11 São chamados de "médiuns" os especialistas rituais que conduzem o ritual do toré. Tais especialistas têm como característica diferencial possuírem 'corrente', ou seja, estabelecerem contatos com os "encantos de luz". A ideia de "doutrinar" se refere ao ato de um especialista ritual experiente formar pessoas que têm "corrente" a lidar com elas e a desenvolver o "trabalho do toré". 
estabelecimento do terreiro, a circulação de pessoas para participação no ritual se restringia ao circuito situado no oeste da área indígena, entre as localidades de Santa Rosa, Lagoa ${ }^{12}$ e o Quiridalho, ou ainda de pessoas que eram levadas eventualmente por Seu Elias.

O movimento de visita ritual para o toré entre a Mina Grande e o lado oeste da atual área indígena, onde estão Quiridalho e Santa Rosa, se dá por mediação de Seu Elias. Quem introduz o ritual do toré na Mina Grande são dois indígenas que chegam à região para contribuir no processo de organização política daquela comunidade na década de 1970: Dôca e Zé Índio, ambos frequentadores do terreiro de Seu Elias, em Ibimirim. É nesse contexto que os recém-iniciados no toré começam a frequentar o terreiro do Quiridalho: "Vinha o pessoal da Ponta da Vargem, Riachinho, da Mina Grande mesmo" (Sesser, Aldeia Quiridalho, julho de 2013).

Essa relação vai se constituindo também como uma relação de aliança política, nesse contexto de reivindicação territorial, e os frequentadores do terreiro de Santa Rosa e Quiridalho, que já haviam participado do levantamento da aldeia Kambiwá, acabam por participar do movimento de resistência na Mina Grande, fortalecendo os laços e ampliando as redes, e assim, após o movimento do "Corte dos arames" continuam a frequentar-se:

Depois do "Corte dos arames" vinha aquela Maria de João de Mariano, ela vinha, ela que puxava a turma, de pés. Nos últimos cortes dos arames lá, a gente participou lá, junto do pessoal da Mina Grande, e Dona Maria com aquele Zé Bebinho, Zé Caetano, aqueles mais velhos. João Salu, Dona Candinha, vinha muita gente de lá, e desse Riachinho, a finada Mariinha, Luzia, finada. A finada Mariinha de Pipiu que era do Tabuleiro. Nos derradeiros a gente acompanhava, eu, Antônio, Maria, irmã dele, Lurdinha, daqui só ia nós. (Sesser, Aldeia Quiridalho, julho de 2013).

No mapa a seguir, expresso essas redes. No círculo azul escuro, está representada a circulação que ocorria entre as aldeias da região situadas a oeste da atual área indígena. Nos círculos vermelho, amarelo e verde estão as redes iniciais, criadas com a chegada de Dôca e Zé Índio, formadas pelo toré na Mina Grande, que era composta por algumas famílias das regiões circunvizinhas - como Tabuleiro, Ponta da Vargem, Pau Ferro Grosso, Julião e Macaco, Baixa da Palmeira. Nos vetores mais espessos, em verde e roxo, represento o translado entre Mina Grande (e arredores) e Quiridalho.

\footnotetext{
${ }^{12}$ A Lagoa é uma localidade vizinha da comunidade que, no mapa, aparece como Marias Pretas, chamada de Lagoa Marias Pretas.
} 


\section{MAPA 5 - CIRCULAÇÃO POR OCASIÃO DO TORÉ}

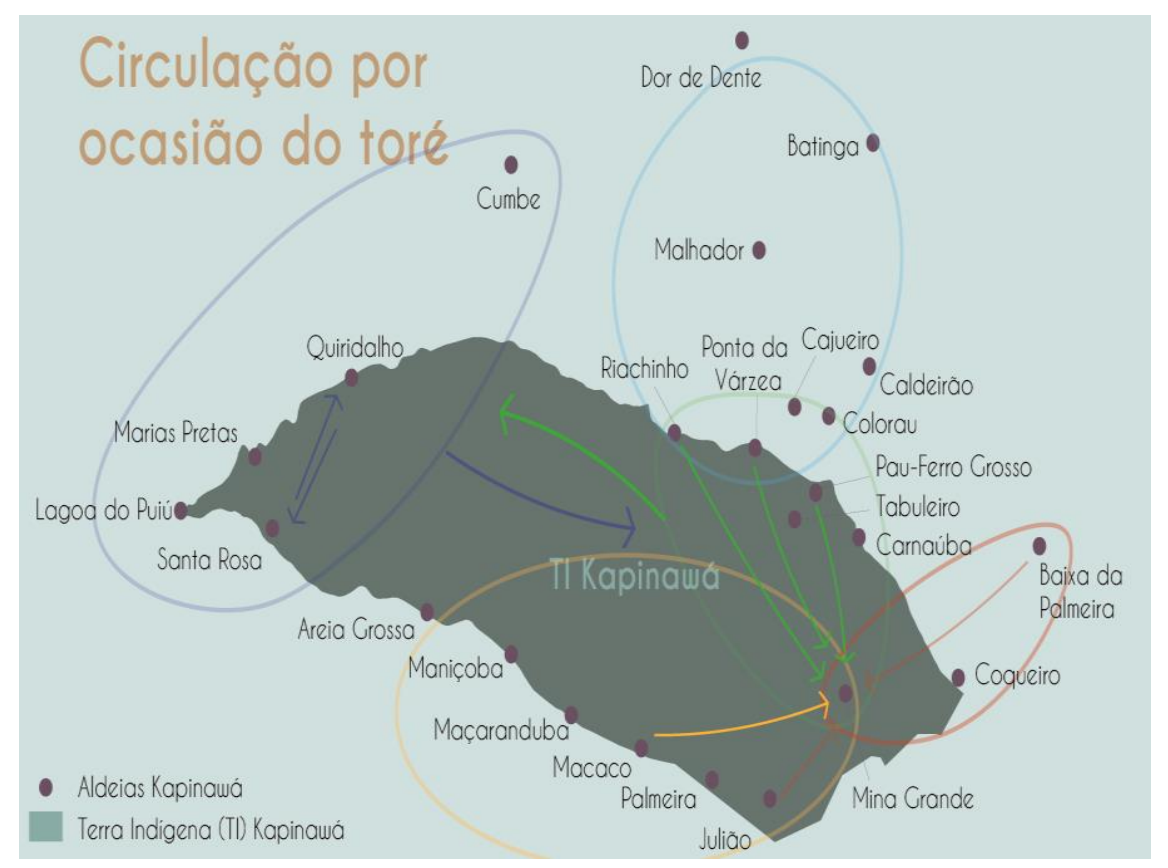

Foi nesse movimento que dançar o toré e ter um médium que guie o ritual solidificou-se como elemento central da afirmação da identidade indígena Kapinawá. E, é importante mencionar, que isso perdura até hoje: por exemplo, meus interlocutores na região da Ponta da Vargem - Riachinho, Pau Ferro Grosso, Tabuleiro - verbalizam a preocupação pela morte dos médiuns dessa localidade e a falta de novas pessoas que possam conduzir o ritual; expressam claramente que apenas na Mina Grande e no Quiridalho têm pessoas que podem cumprir esse papel:

Porque no toré tem os que puxam e os que respondem. Quem puxa é médium. Aqui [na região da Ponta da Vargem] só tinha Mariinha e Edson, agora não tem mais ninguém, a gente só responde, eles cantam lá e nós respondemos. Na Ponta da Vargem não tem [médium], só na Mina Grande, se eles não vierem, quem puxa? Que nem o menino estava dizendo, como é que esse povo da Área Nova vai dançar o toré se não tem um que puxe pra cantar? Só dança toré se esse povo [da Mina Grande e Quiridalho] tiver, se Zé de Caetano, ou o cacique for pra um canto desse. No Quiridalho tem Sesser e tem Antônio, ele mora em Buíque, mas quando precisa ele vem. (Seu Cícero, Aldeia Pau Ferro Grosso, maio de 2013).

É interessante perceber nesse trecho de fala de seu Cícero que ele destaca o fato da Área Nova não ter nenhum médium que guie a realização do toré, no tempo da minha pesquisa do mestrado, em 2013. Isso evidencia o já antigo entendimento das pessoas que participaram do "Corte dos arames" na década de 1980, de que a identidade indígena Kapinawá está fortemente ligada à prática do toré ${ }^{13}$.

\footnotetext{
13 Para essas pessoas que participaram do "Corte dos arames", a identidade indígena também esteve, ao longo de algum tempo, estreitamente relacionada com a participação nesse movimento de resistência da Mina Grande.
} 
Se voltarmos para o Mapa 5 das redes formadas pelo toré, veremos que, se por um lado a região chamada de Área Nova integrava as redes formadas pelo samba de coco e novenas, por outro, estava fora do circuito inicial do toré, pois essa passava por um processo político de reivinvidicação da identidade distinto do processo da Mina Grande, como mencionei no início deste artigo.

O processo de territorialização das famílias dos arredores da Serra do Macaco e a assunção da identidade indígena Kapinawá se deram em momentos diferentes, por comunidades diversas. Essas comunidades mencionadas, que não estavam inseridas no regime do toré quando ocorreu o "Corte dos arames", começam a fazer parte do mesmo ainda na década de 1990, quando de sua organização e reivindicação da identidade indígena Kapinawá. Porém, essa inserção no toré vai ocorrer de forma distinta: não estão presentes nesse momento, por exemplo, Seu Elias, Dôca e Zé Índio, especialistas rituais que "doutrinaram" as pessoas da Mina Grande e do Quiridalho14.

Assim, não é de estranhar o mencionado investimento das aldeias da Área Nova nas novenas, como no Malhador, e a construção da "oca" que foi montada para o toré e era o mesmo espaço de realização da novena de Nossa Senhora de Guadalupe, antes da construção da capela. Há igualmente um segundo movimento, que foi iniciado já depois do término de minha dissertação, em 2014, no qual pessoas da Área Nova, particularmente da aldeia Malhador, começaram a ter pessoas doutrinadas, que agora são médiuns e podem então "puxar" o ritual.

\section{CONSIDERAÇÕES FINAIS}

Para terminar essa reflexão sobre como as práticas rituais operaram/operam na construção da identidade indígena kapinawá gostaria de retomar a diferença apontada por Barth (2005) entre etnicidade X cultura, ou ainda organização social X materiais culturais. Minha ideia é, a partir desta diferenciação, explicitar como a segunda opera na construção da primeira. Рara o autor, "boa parte da confusão (e talvez também da importância premente) a respeito dos grupos étnicos surge dessa tensão entre a natureza dos grupos sociais e a natureza dos materiais culturais sobre os quais se baseia a definição de grupos étnicos como unidades sociais" (2005, p. 17).

\footnotetext{
${ }^{14}$ Aqui é importante fazer uma observação em relação aos especialistas rituais do toré. Um primeiro aspecto a se mencionar é que não existe um consenso sobre como proceder o ritual. Isso se deve às diferentes trajetórias que foram traçadas por esses distintos especialistas ao longo de suas vidas. Sesser, por exemplo, tem sua formação vinculada aos ensinamentos de Seu Elias, e também é marcada pelo período que morou em Boa Vista, localidade próxima à cidade de Ibimirim; Seu Arlindo tem sua formação marcada pelo longo período em que morou em Petrolândia e pelas passagens por São Paulo; e Zé de Caetano, por frequentar outros terreiros nas cidades dos arredores, como o de Nivaldo, em Tupanatinga. Há uma tensão sobre o que deve ou não ser trabalhado nos rituais, e o que seria ou não pertencente a um ritual indígena.
} 
Os dois fenômenos - etnicidade e cultura - estão relacionados, mas não podem ser reduzidos um ao outro. Isso pode ser melhor observado se nos atermos a três ideias. A primeira delas é que a cultura transborda os limites do grupo étnico, ou seja, os materiais culturais não são exclusivos de um grupo étnico (BARTH, 2005, p.17). No caso em estudo, isso pode ser percebido a partir da observação das diferentes correntes de tradição cultural que compõem o repertório ritual kapinawá: a novena, proveniente do que é genericamente conhecido como catolicismo popular; o samba de coco, festejo praticado em toda a região; e, por fim, no toré, ritual difundido como indígena em todo a região Nordeste e que foi aprendido pelos Kapinawá no contexto de reivindicação da identidade indígena.

Uma segunda característica da cultura é que ela é resultado da experiência das pessoas e é entre elas distribuída de forma desigual. Na discussão que apresentei das experiências rituais kapinawá isso ficou explícito, por exemplo, na forma como diferentes grupos familiares incorporaram o toré, em momentos diferentes, em seus próprios repertórios: na década de 1960, notadamente nas aldeias a oeste da TI Kapinawá, encabeçados por Antônio do Quiridalho e Cazuza da Santa Rosa; na região central, aldeia Mina Grande, fim da década de 1970, tendo como protagonistas Dôca e Zé Índio - em ambos momentos contando o seu Elias e seu terreiro com o grande articulador; e, por fim, quarenta anos depois, nos anos de 2010, na aldeia Malhador, encabeçado pela família Amâncio.

A ideia de que esse ritual é vivido de forma desigual pode ser percebida, tomando novamente o toré como exemplo, a partir da diferenciação entre os médiuns - especialistas responsáveis pelo contato entre esse mundo e o mundo dos encantados - e os que respondem, que não tem essa habilidade, mas participam do ritual, elemento fortemente sublinhado por seu Cícero Frazão. Ou ainda, no samba de coco, pelos cantadores profissionais e os que dançam. Esses exemplos dão sentido à argumentação do autor de "que um aspecto crucial das coisas culturais é a forma pela qual elas se tornam diferencialmente distribuídas entre pessoas e entre círculos e grupos de pessoas" (BARTH, 2005, p.17).

Uma terceira característica da cultura é que ela "está em um estado de fluxo constante", ou seja, "não há a possibilidade de estagnação nos materiais culturais, porque eles estão sendo constantemente gerados, à medida que são induzidos a partir das experiências das pessoas" (BARTH, 2005, p.17). Essa ideia de mutabilidade de cultura ficou clara nos processos apontados de etnificação das novenas e dos sambas de coco e, igualmente o movimento inverso, de influência das tradições locais que foram agregadas ao toré quando de sua inserção. Ou ainda na incorporação do toré na Área Nova ao longo dos últimos anos.

Meu intuito, ao narrar como a cultura opera - ou melhor, as correntes de tradição cultural -, foi mostrar como elas foram centrais na construção dos conteúdos ideativos de comunidade e também da construção de redes sociais que possibilitou a posterior 
organização e reivindicação da identidade indígena kapinawá. Ao fazer suas próprias leituras das correntes de tradição cultural que perpassam suas vidas, as experiências das famílias e das pessoas possibilitaram uma forma muito particular de vivenciar esses rituais, particularizando-as em uma tradição de conhecimento kapinawá e delimitando quais são os elementos das mesmas que marcam seus sinais diacríticos e formam as fronteiras étnicas do ser Kapinawá ao longo das décadas.

\section{REFERÊNCIAS}

ALBUQUERQUE, Marcos Alexandre dos Santos. 0 Torécoco (a construção do repertório musical tradicional dos índios Kapinawá da Mina Grande - PE). Dissertação de Mestrado. Campina Grande: Programa de Pós-Graduação em Sociologia/PPGS UFCG, 2005.

28, n. 2, p. 57-79, 2008.

0 dom e a tradição indígena Kapinawá. Religião e Sociedade, Rio de Janeiro, 2v.

$249-263,2009$

0 Dom: um ensaio estético. Revista de Ciências Humanas, EDUFSC, v. 43, n. 1, p.

ANDRADE, L. E. A.; DANTAS, M. S. . 0 tempo e a terra: Mapeando o Território Indígena Kapinawá. 1. ed. Olinda: CCLF, 2017.

ANDRADE, Lara Erendira A. Pelejas indígenas: conflitos territoriais e dinâmicas históricas na Serra do Catimbau. Tese de Doutorado PPGA/UFPE. Recife, 2020.

. Kapinawá é meu, já tomei, tá tomado: Organização social, dinâmicas territoriais e processos identitários entre os Kapinawá. Dissertação de Mestrado. João Pessoa: Programa de Pós-Graduação em Antropologia/PPGA UFPB, 2014.

BARNES, John A. Redes Sociais e Processo Político. In: FELDMENN-BIANCO (org.): Antropologia das Sociedades Contemporâneas, São Paulo: Global, 1987. p. 159-193.

BARTH, Fredrik. Cosmologies in the making: a generative approach to cultural variation in inner New Guinea. Cambridge: Cambridge University Press, 1987.

"A análise da cultura nas sociedades complexas". In: BARTH, Fredik. 0 guru, 0 iniciador e outras variações antropológicas, Rio de Janeiro: Contra Capa, 2000. p. 107-139. Etnicidade e 0 Conceito de Cultura. Antropolítica, v. 2, n.19, p. 15-30, 2005.

GRUNEWALD, Rodrigo de Azeredo. Toré e jurema:emblemas indígenas no nordeste do Brasil. Cienc. Cult., v.60, n.4, p. 43-45, 2008.

HANNERZ, Ulf. Fluxos, fronteiras, híbridos: palavras-chave da antropologia transnacional. Mana, v.3, n. 1, p. 7-39, 1997.

MURA, Claudia. Todo mistério tem dono!: Ritual, política e tradição de conhecimento entre os Pankararu. Rio de Janeiro: Contra Capa, 2013. 
MURA, Fabio; DA SILVA, Alexandra Barbosa. Organização doméstica, tradição de conhecimento e jogos identitários. Raízes: Revista de Ciências Sociais e Econômicas, v. 31, n. 1, p. 96-116, 2011.

MURA, Fábio; PALITOT, Estêvão Martins; MARQUES, Amanda Christinne Nascimento. Relatório Tabajara: Um estudo sobre a ocupação indígena no Litoral Sul da Paraíba. João Pessoa: Editora da UFPB, 2015.

OLIVEIRA, João Pacheco. 'Uma etnologia dos 'índios misturados'? Situação colonial, territorialização e fluxos culturais". In: OLIVEIRA, João Pacheco (0rg.). A viagem da volta etnicidade, política e reelaboração cultural no Nordeste indígena, Rio de Janeiro: Contra Capa, 1999. p. 11-40.

PEREIRA, Edmundo. "Benditos, toantes e sambas de coco: notas para uma antropologia da música entre os Kapinawá de Mina Grande". In: GRÜNEWALD (org): Toré: Regime Encantado dos Índios do Nordeste. Recife: Ed. Massangana (FUNDAJ). 2004. p. 299-328.

"Música indígena, música sertaneja: notas para uma antropologia da música entre os Índios do Nordeste brasileiro". In: OLIVEIRA (org): A presença indígena no Nordeste, Rio de Janeiro: Contra Capa, 2011. p. 557-604.

WILK, Richard R. Households in Process: Agricultural Change and Domestic Transformation among the Kekchi Maya of Belize. In: ARNOULD, E.; NETTING, R.; WILK, R. HOUSEHOLDS Comparative and Historical Studies of the Domestic Group. Berkeley, Los Angeles, London: University of Califórnia Press, 1984. p 217-244. 